\title{
Is there a room for optimism for the near-future enlargement of the European Union?
}

\author{
Daviti Mtchedlishvili \\ University of Canterbury \\ daviti.mtchedlishvili@pg.canterbury.ac.nz \\ "EU membership is yours, but reforms vital"
}

Juncker (March, 2018)

\begin{abstract}
The sense of optimism for the enlargement of the European Union in the near-future has been evaporating. A new strategy paper on EU enlargement which was issued by the European Commission in February 2018 seems to still be based on a 'fatigue from expansion' approach to enlargement, even though it states that Serbia and Montenegro 'could potentially be ready for membership [by] 2025'. This paper discusses the bumpy road the Western Balkan states have faced towards EU accession from the early 2000 s to the present day. In addition to more challenging domestic political and economic conditions, these states have also been required to meet tougher and more variable accession conditions in comparison to the post-communist states that joined the EU in and after 2004. The inconsistency and vagueness of the EU approach to the accession of the Western Balkan states remains the most important factor behind the continued postponements of their accession dates.
\end{abstract}

Keywords: EU enlargement, Western Balkans, conditions, vague approach

The enlargement policy is a key instrument for the European Union (EU) to promote democracy, rule of law and human rights (Börzel and Schimmelfennig, 2017). The 'golden carrot' of accession has been identified as the core of the EU's integration capacity beyond its borders (Börzel et al., 2017). Enlargement has a wide range of impacts and consequences on actors, ranging from the decision-making processes to institutional structures and transformations. For this reason, the enlargement process closely influences the public discourse and increasingly affects the political agenda and voter behaviour (Larsen, 2010).

The conceptualisation of the EU's policy towards the Western Balkans is marked by a strong democratic conditionality and different levels of the EU's involvement in the regional dynamics. The conditions set out at the Copenhagen European Council in 1993 were designed to minimise the risk of new entrants becoming politically unstable and economically burdensome to the existing EU (Grabbe, 2006). The establishment of democracies and market economies in the EU has advanced side by side with the promotion of human rights and the rule of law. This set of concepts and/or core norms on which the EU was established (Manners, 2002) has been successfully promoted in 
the immediate vicinity of the Union, East Central Europe, the Baltics and the Western Balkans.

However, this set of the EU's norms has not been promoted with the same success in all the European countries and regions which were exposed to its promotion. Some key benchmarks which the EU has set regarding compliance with the Copenhagen conditions, particularly the ability of the candidate countries to successfully strengthen democratic institutions, respect for the rule of law and human rights, the fight against corruption, and the peaceful settlement of disputes, seemed to be more challenging for the post-communist countries from the Western Balkans than for their counterparts from Central Europe and the Baltics. Moreover, the EU has been firmer regarding compliance with the Copenhagen accession criteria for new candidates since the 2004o7 enlargement round, and that has caused subsequently slower progress in association/accession and stagnation in post-communist reform (Petrovic, 2013). In fact, in 2006, the European Council introduced a tougher tool for the adoption and implementation of acquis chapters for the current and new membership candidate countries. The Western Balkan aspiring members are facing an additional set of politically sensitive conditions, often colloquially referred to as the 'Copenhagen Plus' criteria, which relates to the respect for and implementation of various political and peace agreements stemming mostly from the armed conflicts of the 1990s (European Commission, 2006).

EU enlargement with the determination of the Copenhagen Criteria was first portrayed as an indispensable tool for the transfer of 'European values'. For this purpose, it has been argued that EU expansion to the East aims to spread European values to non-EU counties. According to Diez (2005, p. 630), the Copenhagen Criteria themselves are evidence of this priority mission of the EU. Manners (2002) supported this argument and defined the change and transformation that takes place in the candidate countries under the influence of membership conditions as the "normative power of Europe". Especially after the so-called "big bang" enlargement of 2004, a rhetoric has been developed to "unite the East and the West of Europe" and eventually has given the EU an unprecedented influence in the region by the creation of rules and the transfer of given EU rules internally and externally (Schimmelfennig and Sedelmeier, 2004).

Preoccupied with dealing with its internal challenges (such as BREXIT, the refugee crisis, the rise of nationalism), the EU's enlargement policy for the 'unification of the East and the West of Europe' has been frozen on an 'auto-pilot mode' (Kmezić and Bieber, 2016). However, the president of the European Commission, Jean-Claude Junker, in his 2017 'State of the Union address' announced that the 'wind is back in EU's sails' and that the EU must maintain a credible enlargement perspective for the Western Balkans (European Commission, 2017). In order to stimulate this process, the European Commission adopted a new strategy for enlargement into the Western Balkans (European Commission, 2018). The document states that the EU 'could' become larger than 27 Members by 2025. The European Commission would like to speed up the accession of the Western Balkans to the EU but once the tightened Copenhagen Criteria are met. The priorities are: the rule of law and judicial reforms, fundamental rights, economic development and competitiveness and good neighbourly relations (European Commission, 2018, p. 6).

Previously, Brussels had announced the prospects for EU membership in the Western Balkans with an uncertain time perspective (once the conditions were met), but now, 
in February 2018, this prospect was firstly confirmed and, secondly, the specific date of the first possible accession was announced - 2025. 'With strong political will, the delivery of real and sustained reforms and definitive solutions to disputes with neighbours', Serbia and Montenegro could potentially be ready for membership in a 2025 perspective (European Commission, 2018, p. 2). Back in 2014, Jean-Claude Juncker, at that time a candidate for the presidency of the European Commission, announced that the EU was in need of a break from enlargement to 'consolidate what has been achieved among the 28' (Juncker, 2014, p. 12). In his opening statement in the European Parliament plenary session, Junker advocated keeping a European perspective for the Western Balkans, but with no further enlargement over the succeeding five years.

Montenegro and Serbia are the current front-runners in the accession process. They are currently the only candidates engaged in accession negotiations, but Serbia in particular faces serious challenges on its way to accession. It is required to meet interim benchmarks related to the normalisation of relations with Kosovo (Chapter 35) and to sign a comprehensive, legally binding agreement with Kosovi, if it wants to complete its accession (European Commission, 2018) as discussed in Petrovic and Wilson's contribution to this issue.

From 2019, after the election of the European Parliament, a new political cycle in the EU will begin. Therefore, the European Commission has already set common tasks for this period in relation to the Western Balkans. If the set of goals is achieved, then by the end of the next cycle the European Union might admit new members - specifically Serbia and Montenegro. The chance of membership for these states will give an impetus to other countries from the Western Balkans to intensify their European aspirations and belief that the European perspectives are real.

The possible accession of Serbia and Montenegro in 2025 will be the first enlargement of the EU since 2013, when the first state from the Western Balkans, Croatia, was accepted as a new member of the Union. However, membership for Serbia and Montenegro is not guaranteed in 2025. President Juncker has announced that the EU would not accept any new members with unresolved territorial issues (RFE/RL's Balkan Service, 2018). The reference in this announcement is the hitherto unresolved territorial and maritime dispute between Croatia and Slovenia. Prior to Croatia's EU accession on 1 July 2013, this conflict had led to a blockade of the accession negotiations of Croatia by Slovenia, thus creating some coercive momentum to 'solve' the conflict during Croatia's accession negotiations (Bickl, 2017). Despite the fact that the International Arbitration Court in The Hague in June 2017 ruled in favour of Slovenia, Croatia has so far refused to accept and comply with the international arbitration ruling, despite the pressures from Brussels (Ilic, 2017). This case shows that during any bilateral issues, the member state(s) of the European Union might use their 'inside-the-club' status to enforce their position vis-à-vis candidate countries (Uilenreef, 2010; Bickl, 2017). Nevertheless, Croatia, with unresolved territorial disputes, had managed to become the member of the EU, while a similar pattern of bilateral issues introduced into accession negotiations has appeared to emerge in the ongoing negotiations between the EU and Serbia over Kosovo. If the EU adheres to the present operational design of dealing with bilateral questions in the context of accession negotiations (for example the Slovenia-Croatia border dispute per se), EU enlargement might be at risk in the foreseeable future. 
In addition to the obligation for the candidate countries to settle their disputes peacefully, they continue to be required to fulfil the Copenhagen criteria - especially with regard to ensuring the rule of law, economic stability and the ability of the state to apply the necessary reforms. The reforms and changes to their legal and institutional order that the Western Balkan candidates for EU membership need to introduce in order to address the EU's conditional policy demands require significant funding by means of the Instrument for Pre-accession Assistance (IPA) and other forms of EU financial and technical help. As the new strategy of the European Commission to the Western Balkans states: 'to ensure a smooth transition to membership, it is necessary to ensure adequate funding' (European Commission, 2018, p. 18).

In this regard, the European Commission has proposed an insignificant increase in the Instrument for Pre-accession Assistance II. The Instrument for Pre-accession Assistance (IPA) targets countries that are candidates or potential candidates for EU membership. The program supports adopting and implementing the EU acquis communitaire, namely political, institutional, legal, administrative, social and economic reforms (European Commission, 2014b). The first IPA regulation came into force in 2007, which replaced the pre-accession assistance programs, delivered under several thematic (PHARE, SAPARD, ISPA) and geographical (CARDS) instruments (Koeth, 2014). For the 2014-2020 multiannual financial framework (MFF), the European Commission implemented regulations (No 231/2014), which established an Instrument for Pre-accession Assistance named IPA II (European Commission, 2014b). For the period 2007-2013, IPA I had a budget of EUR 11.5 billion, while its successor, IPA II will have EUR 11.7 billion for the period 2014-2020 (Koeth, 2014). The new IPA II clearly reflects the fact that the enlargement process was in a holding pattern. According to the new strategic paper (European Commission, 2018), the Commission proposes gradually increased funding under the Instrument for PreAccession Assistance to cater for possible accessions.

Most of the EU's financial assistance to the Western Balkans goes to sectoral reforms to strengthen the rule of law, sustainable economic development, competitiveness, democracy and judiciary. It is noteworthy that these target those areas in which the European Commission sees the biggest deficit. The new strategic document states the region should take these fundamental values of the EU much more resolutely and reliably (European Commission, 2018). The Western Balkan economies are characterised by a lack of competitiveness due to excessive political interference and insufficient development of the private sector, which slows growth and reduces employment prospects for young people (The World Bank Group, 2017). It is obvious that the Western Balkan countries are in need of economic reform programs. According to the World Bank, the medium term economic outlook is rather positive: growth is projected to reach 3.6 per cent by 2019 which would be significantly above the EU average (Table 1.1). 
Table 1.1: The medium-term growth outlook for the Western Balkans

\begin{tabular}{|l|c|c|c|c|}
\hline $\begin{array}{l}\text { Real GDP growth (annual } \\
\text { rates) }\end{array}$ & $\mathbf{2 0 1 6}$ & $\mathbf{2 0 1 7}$ & $\mathbf{2 0 1 8}$ & $\mathbf{2 0 1 9}$ \\
\hline Albania & 3.4 & 3.8 & 3.6 & 3.5 \\
\hline Bosnia and Herzegovina & 3.1 & 3.0 & 3.2 & 3.4 \\
\hline Kosovo & 3.4 & 4.4 & 4.8 & 4.8 \\
\hline Macedonia, FYR & 2.4 & 1.5 & 3.2 & 3.9 \\
\hline Montenegro & 2.9 & 4.2 & 2.8 & 2.5 \\
\hline Serbia & 2.8 & 2.0 & 3.0 & 3.5 \\
\hline WB6 & $\mathbf{2 . 9}$ & $\mathbf{2 . 6}$ & $\mathbf{3 . 3}$ & $\mathbf{3 . 6}$ \\
\hline
\end{tabular}

Source: The World Bank Group, 2017

However, even if these figures are achieved, the economies of the Western Balkans will need at least 15 to 20 years to catch up to the EU's average economic performance (Fouéré, 2018).

The large-scale military violence that devastated the region in the 1990 s is no longer an urgent problem for the Balkans. Even so, economic weakness, growing public frustration and unemployment are the main local irritants for European integration (Börzel and Sedelmeier, 2017; The World Bank Group, 2017; Fouéré, 2018). In order to reverse the current trends, the resolution of economic problems is an obvious means of achieving concrete political results. Therefore, the increased funding is required to ensure steady growth and successful European integration.

Past experiences show that the EU has tried to gradually extend the European perspective in Western Balkan countries. The European Commission's 'three pillar' approach introduced during 2012-2014 (see the Introduction to this issue) which brought chapters 23 (judicial system and fundamental human rights) and 24 (justice, freedom and security) into the centre of the EU accession process aimed to better prepare the candidate countries for accession and therewith 'ensure [that] enlargement is not at the expense of the effectiveness of the Union' (European Commission, 2014a, p.1). These chapters have to be 'opened early in the process and closed at the end to allow maximum time for solid track records to develop with the aim of irreversibility of reforms' (European Commission, 2014a, p.1). More recently there was the launch of the Berlin Process, which consists of high-level meetings between the six Western Balkan governments and several EU Member States. These efforts were made to keep optimism about EU membership high in the Balkans and refresh the European perspective (Vurmo, 2018). However, in addition to making the EU accession process tougher for the Western Balkan candidates, these attempts were rather narrow and were not able to capture the new socio-economic realities in the region such as (still) high unemployment, low living standards and an increase in public frustration.

Moreover, the (real) motives behind the EU's Enlargement strategy of February 2018 might be more related to the EU's geo-political confrontation with Russia than a genuine attempt at stimulating further reforms and faster accession in the Western Balkan states. The EU fears that the countries of the Western Balkans may fall under the greater influence of Russia, China, and/or Turkey and move away from Europe (Bieri, 2015; Orosz, 2018). Thus, the new strategy of the European Commission for a credible enlargement perspective is a response to Russia's attempts to build political influence in the region, as well as to the growing economic activity of China and the cultural influence of Turkey. 
Regardless, EU foreign ministers disagreed over the integration of the Western Balkans at a European Council meeting that took place in Sofia on 17 May 2018. The meeting discussed the updated EU strategy for the Western Balkans. During the discussion, the European Council split into 'optimists' and 'skeptics; in relation to the European perspective for the Western Balkans. 'Optimist' Hungarian Foreign Minister, Peter Szijjarto, said that the European Union is extremely slow when it comes to issues in the Western Balkans' (euobserver, 2018). According to him, Serbia and Montenegro could join the bloc by 2022. The Austrian Foreign Minister supported this idea in favour of the accelerated integration of the region.

From the 'skeptics bloc' Slovenian Minister of Foreign Affairs, Karl Erjavec, warned that even the 2025 target was "not realistic" due to ongoing border disputes among former Yugoslav countries (euobserver, 2018).

Despite the fact that both 'optimists' and 'sceptics' from the EU have (at least rhetorically) 'welcomed' and 'supported' the Western Balkan countries' in advancing their European values, and aspirations for EU membership (European Council, 2018) for 15 years since the Thessaloniki summit, the Western Balkan summit in Sofia clearly showed a vague and equivocal support of the leaders of core EU member states for the "European perspective" of the Balkans. Until recently, "fatigue from expansion" has reigned in the European Union. A stalled expansion has reduced the enlargement drive in the Western Balkans and greatly increased the public frustration.

With regards to EU accession prospects, pessimism continues to grow (Figure 1.1) given that there were fewer people in 2016 who forecast accession to the EU as early as 2020 (2014:27 per cent ; 2015: 24 per cent; 2016: 19 per cent). The highest proportion of respondents still feels that their country will never integrate into the EU ( 28 per cent), with pessimists particularly numerous in Bosnia and Herzegovina (33 per cent) and Serbia (38 per cent) (Balkan Barometer, 2017).

Figure 1.1: Percentage distribution of answers to the question: 'In general, when do you expect the accession to EU to happen?'

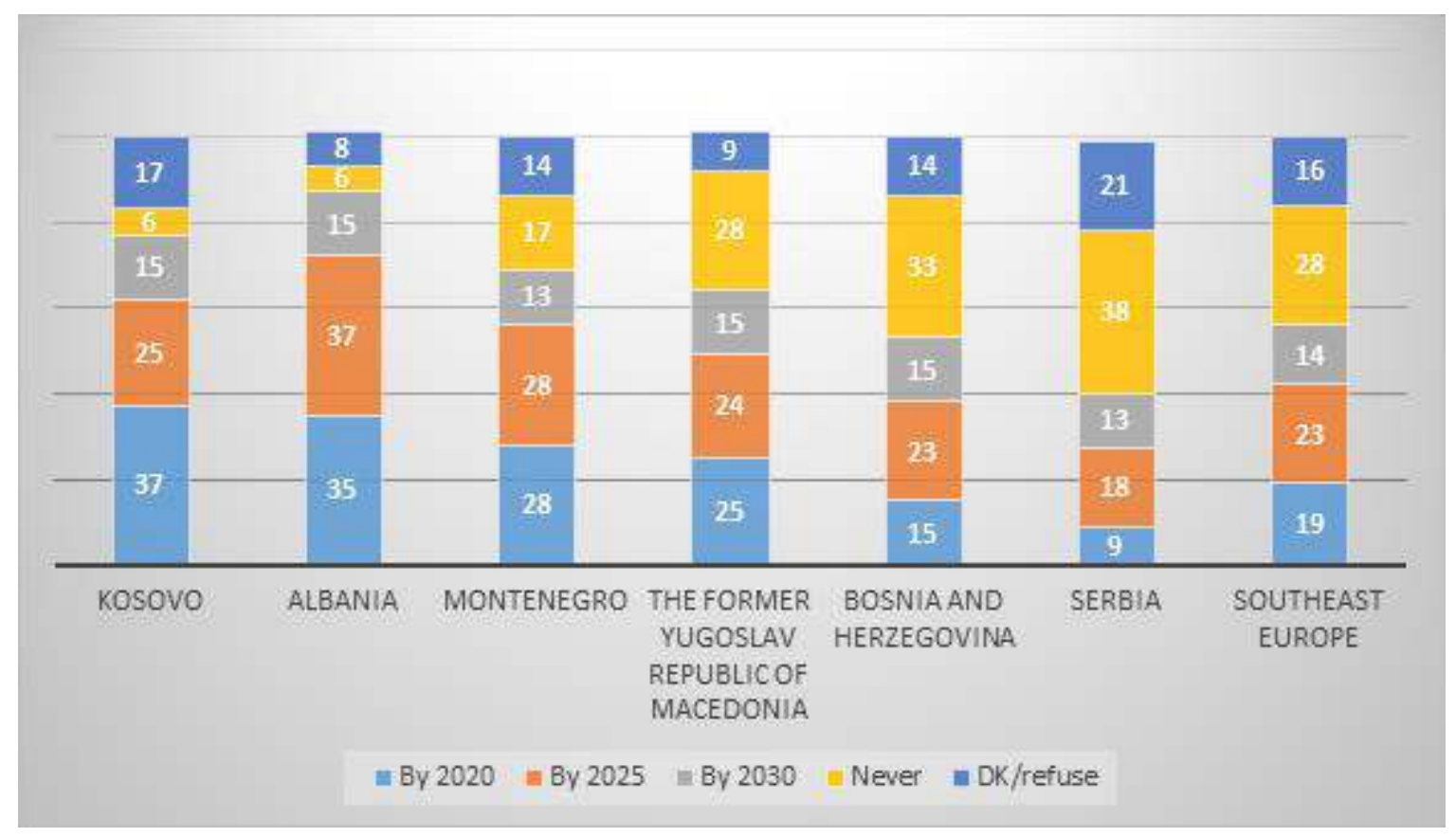

Source: Balkan Barometer 2017 
Needless to say, for the admission of new members to the European Union the unanimous support of all the current EU states is needed. The Accession Treaty will be examined by the Commission, EU Council and the European Parliament before a unanimous decision is adopted by the Council of the European Union. The Treaty is, subsequently, signed by the candidate country and by representatives of all EU Member States (European Commission, 2015). The European Council ministerial meeting showed that there might be at least one recalcitrant and 'receptive' government from the 'skeptic's bloc' to overturn the entire construction of the accession of the Western Balkans. Hence, the Balkan countries might not become members in the foreseeable future, not due to the lack of reforms, but due to political deadlocks.

Therefore, it seems fair to say that so far, the adoption of the updated EU strategy for the Western Balkans has not gone much further than encouraging Serbia to recognise Kosovo. It remains to be seen how far the European Commission will be able to advance its proposals on the accession of the Western Balkans by 2025 .

The lack of financial assistance, vague accession dates, the same wording of the "European Perspective" and skeptical heads of the member states are the reason for today's less optimistic view on prospects for enlargement of the European Union in the near future. There are several reasons why the integration of the Western Balkans in general, and Serbia in particular, is so slow. As noted above, they can be divided into internal and external. But one of the most important catalysts lies in the inconsistency and vagueness of the EU 'approach' to the accession of the Western Balkan states. In a nutshell, conditionality works well if membership criteria are clear, if the same criteria are applied to all applicants, if they are strictly but fairly monitored, if the findings are transparently communicated, and if there is no doubt that the reward will come, once conditions are met.

\section{Bibliography}

Balkan Barometer (2017). Public Opinion Survey: Regional Cooperation Council (available at: www.rcc.int/seeds/files/RCC_BalkanBarometer_PublicOpinion_2017.pdf).

Bieri, M. (2015). The Western Balkans between Europe and Russia. CSS Analyses in Security Policy No.170 (March), pp. 1-4 (available at: http://www.css.ethz.ch/content/dam/ethz/special-interest/gess/cis/center-forsecurities-studies/pdfs/CSSAnalyse170-EN.pdf).

Börzel, T. A., Dimitrova, A. and Schimmelfennig, F. (2017). European Union enlargement and integration capacity: concepts, findings, and policy implications. Journal of European Public Policy 24 (2), pp. 157-176.

Börzel, T. A. and Schimmelfennig, F. (2017). 'Coming together or drifting apart? The EU's political integration capacity in Eastern Europe', Journal of European Public Policy 24 (2), pp. 278-296.

Börzel, T. A. and Sedelmeier, U. (2017). 'Larger and more law abiding? The impact of enlargement on compliance in the European Union', Journal of European Public Policy 24 (2), pp. 197-215. 
Bickl, T. (2017). 'Reconstructing the Intractable: The Croatia-Slovenia Border Dispute and Its Implications for EU Enlargement', Croatian Political Science Review, (54) 4, pp. 7-39.

Diez, T. (2005). 'Constructing the Self and Changing Others: Reconsidering 'Normative Power Europe”, Millennium: Journal of International Studies, 33(3), pp. $613-636$.

Grabbe, H., (2006). 'The EU's Transformative Power: Europeanization through Conditionality in Central and Eastern Europe', New York: Palgave Macmillan.

Emini, D. and Stakic, I. (2018). Belgrade and Pristina: lost in normalisation? European Union Institute for Security Studies (EUISS), April (2018 (available at: https://www.iss.europa.eu/sites/default/files/EUISSFiles/Brief 5 Belgrade and Pristina.pdf)

European Commission (2006). Enlargement Strategy and Main Challenges 20062007. Including annexed special report on the EU's capacity to integrate new members. Communication from the Commission to the European Parliament and the Council, COM (2006) 649 final, Brussels, 8 November.

European Commission (2014a). Enlargement Strategy and Main Challenges 201415. COM (2014) 700 final, Brussels 8.10.2014.

European Commission (2014b). Commission Implementing Regulation (EU) No 447/2014 of 2 May 2014 on the specific rules for implementing Regulation (EU) No 231/2014 of the European Parliament and of the Council establishing an Instrument for Pre-accession assistance (IPA II). Official Journal of the European Union. 3.5. 2014, pp.32-52.

European Commission (2015). European Neighbourhood Policy and Enlargement Negotiations (available at: http://ec.europa.eu/enlargement/neighbourhood/countries/egypt/index_en.htm).

European Commission (2017). President Jean-Claude Juncker's State of the Union Address 2017, Brussels, 13 September 2017 (Available at: http://europa.eu/rapid/press-release_SPEECH-17-3165_en.htm.

European Commission (2018). A credible enlargement perspective for and enhanced EU engagement with the Western Balkans. COM (2018) 65 final.'

European Council (2018). Sofia Declaration. 17 May 2018', (May), pp. 1-7 (available at: http://www.consilium.europa.eu/media/34776/sofia-declaration_en.pdf).

European Parliament (2015). The Western Balkans and EU Enlargement: Lessons learned, ways forward and prospects ahead. Brussels: Policy Department, DirectorateGeneral for External Policies (available at: http://www.europarl.europa.eu/RegData/etudes/IDAN/2015/534999/EXPO IDA(2015)534999 EN.pdf).

European Parliament Briefing (2016). The Western Balkans' Berlin process: A new impulse for regional cooperation. (available at: http://www.europarl.europa.eu/RegData/etudes/BRIE/2016/586602/EPRS_BRI(2016)586602_EN.pdf). 
Fouéré, E. (2018). A decisive year for the EU's re-engagement with the Western Balkans. CEPS Policy Insights. No. 2018/o1, January, pp. 1-12.

Ilić, M. (2017). Croatia v. Slovenia: the defiled proceedings'. Arbitration Law Review, 9 (one issue, no pages; available at: https://elibrary.law.psu.edu/arbitrationlawreview/vol9/iss1/11/).

Juncker, J.-C. (2014).A New Start for Europe: My Agenda for Jobs, Growth, Fairness and Democratic Change. Political guidelines for the next European Commission, European Parliament, Strasbourg, 15 July (available at: https://ec.europa.eu/commission/sites/beta-political/files/juncker-political-guidelines-speech_en.pdf).

Kmezić, M. and Bieber, F. (2016). Western Balkans and the EU: Beyond the Autopilot Mode. Policy Brief, BiEPAG (available at: http://www.balkanfund.org/publib/biepag/BIEPAG-Western-Balkans-and-the-EU-Beyond-the-Autopilot-Mode.pdf).

Koeth, W. (2014). The New Instrument for Pre-Accession Assistance (IPA II): Less Accession, More Assistance? Working paper 2014/W/o1. European Institute of Public Administration Institut européen d'administration publique, Maastricht (available at: https://www.eipa.eu/wp-content/uploads/2017/11/20160318134447_WorkingPaper_2014_W_o1.pdf).

Larsen, H. (2010) The Challenges of European Enlargement Implications for the political system of the EU. Jean Monnet Lectures: The politics of the European Union Central structures and processes of the EU, University of Copenhagen (available at: https://politicalscience.ku.dk/international_students/present_international_studen ts/taking_exams/past_papers/The_Challenges_of_European_Enlargement.pdf).

Orosz, A. (2018). What Role Do the External Actors (Russia, China, Turkey, and the European Union) Play in the Western Balkans? KKI 4:1 Series. Institute for Foreign Affairs and Trade (available at: http://kki.hu/assets/upload/10_KKI_4_1_WB_20180515.pdf).

RFE/RL's Balkan Service (2018). EU's Juncker: Serbia Must Resolve Kosovo Dispute to Join Bloc 26 February (available at: https://www.rferl.org/a/eu-serbia-kosovomust-resolve-dispute-to-join/29064188.html).

Petrovic, M., (2013). The Democratic Transition of Post-Communist Europe: In the Shadow of Communist Differences and Uneven EUropeanisation. London: The Palgrave Macmillan.

Schimmelfennig, F. and Sedelmeier, U. (2004). Governance by conditionality: EU rule transfer to the candidate countries of Central and Eastern Europe. Journal of European Public Policy.11 (4), pp. 661-679.

The World Bank Group (2017). Western Balkans 12th Regular Economic Report. No 12 (available at: https://openknowledge.worldbank.org/bitstream/handle/10986/28883/121417-WP-PUBLIC.pdf?sequence=1\&isAllowed=y).

Vurmo, G. (2018). The Western Balkans' EU Dream Ambition calls for a new process. CEPS Papers 2018 (3), pp.1-12 (available at: https://www.ceps.eu/system/files/Vurmo on the Western Balkans.pdf). 